\title{
INFLUENCE OF STORAGE AND HEATING ON MOTHER'S MILK MICROBIOTA
}

\section{Influência do armazenamento e aquecimento na microbiota do leite materno}

\author{
Josefa Gardenas BORRELL, Bruno ZILBERSTEIN, Alina Guimarães QUINTANILHA
}

ABCDDV/633

Borrell JG, Zilberstein B, Quintanilha AG.

ABSTRACT - Background - There is a consensus among many authors that the newborn (NB) is particularly prone to infections of the gastrointestinal tract for multiple factors, such as the hypoxia and the artificial milk. These factors facilitate the abnormal bacterial colonization and promote a drawback in the destruction of the toxins of such bacterias. Aim - To identify the microorganisms in the breast milk, after its storage in the refrigerator at $4^{\circ} \mathrm{C}$, as well as after heating and to relate the eventual clinical NB signs with the microbiologic laboratory results of the breast milk which was offered. Methods - The samples collected contemplated the three phases of post-natal breast milk. In 16 cases, the colostrum type was obtained as yellowish milky secretion, up to the beginning of the second week after the birth. In 14 cases, the transition type was obtained as intermediate product of the mother's milk, between colostrum and the mature milk, between the 7th and the 15 th day after the birth. In 14 cases, the mature type was obtained as a white opaque liquid, of light smell and sweet taste, from the 15th day after birth. The milk types obtained in the three presentations were subdivided according to the period of conservation and heating in the group colostrums, transition and mature. Results - The microorganisms which did not present growth were: Salmonella sp, Molds/leavens and Pseudomonas aeruginosa. The total coliforms and fecal coliforms were observed. There was no significant microorganisms growth. The aerobic mesophiles, Staphilococcus aureus and Bacillus cereus were also observed. These microorganisms presented growth, but the NBs did not present damage in their clinical status. Conclusions - Under this conditions of collecting and storage, there was no fecal coliforms, Salmonella sp, Molds/leavens and Pseudomonas aeruginosa; the microorganisms which grew up, kept themselves above the limits of detection (aerobic mesophiles, total coliforms, Stapholococcus aureus and Bacillus cereus; microbian rates, even when higher than the ones stablished, did not influence the clinical status of the NB; the breast milk collected, transported and stored under the conditions presented in this study can be safely used up to 24 hours after being stored in a refrigerator at $4{ }^{\circ} \mathrm{C}$.

HEADINGS - Milk, human, Microorganisms.

\section{INTRODUCTION}

There is a consensus among many authors that the newborn (NB) is particularly prone to infections of the gastrointestinal tract for multiple factors, such as the hypoxia and the artificial milk. These factors facilitate the abnormal bacterial colonization and promote a drawback in the destruction of the toxins of such bacteria. On the other hand, breast milk has important advantages in many fields such as: nutritional, breastfeeding immunity and the feelings between mother-baby. Due to the vulnerability of the NB to acquire several diseases because of its immature immunologic system, plus the possibility of the worsening situation for the ingestion of raw or "in natura" human milk not handled adequately at home and during its transportation to the hospital, it's important to investigate the microbiota found in this milk, after its storage and heating, before being offered to the NB.

The aim of this study was: a) to identify the microor-

From the Department of Gastroenterology, Hospital das Clínicas, São Paulo, SP, Brazil.

Correspondence to: Josefa Gardenas Borrell, e-mail: cbcd@cbed.org.br ganisms in the breast milk, after its storage in the refrigerator at $4^{\circ} \mathrm{C}$, as well as after heating; b) to relate the eventual clinical NB signs with the microbiologic laboratory results of the breast milk which was offered.

\section{METHODS}

This study was approved by the ethical comitee of the Hospital das Clínicas, São Paulo, SP, Brasil. It was conducted prospectively involving 28 mothers all discharged from this school-hospital post-labour. They were oriented to extract their milk at home and transport it to the nursery so that it could be offered to their high-risk newborn babies. There were 87 samples of breast milk, presented as colostrum, transition and mature, collected after being stored at $4^{\circ} \mathrm{C}$ and after being heated in boiling water at $55^{\circ} \mathrm{C}$ for one minute, before being offered to the NB. The breast milk was analysed by a microbiology food laboratory. The study presented the following criteria of inclusion, regarding the maternal selection: mothers without a history of maternal-fetal infection, which could jeopardize the quality of the milk, with risks to the NB; mothers who didn't make use of antibiotic therapy or other drugs 
which could affect the quality of the milk; mothers who didn't make use of intermediate of silicon adapted to the nipple rim and manual or electrical milking pumps; mothers who had already been discharged from hospital and who would offer their milk to their babies under the conditions mentioned previously, after they had been oriented verbally or through a written text about the necessary procedures performed during the extraction, storage and transportation of the milk to the nursery; mothers who agreed with the inform consent presented.

\section{Samples}

The samples collected contemplated the three phases of the presentation of the post-natal breast milk ${ }^{4}$. In 16 cases, the colostrum type was obtained as yellowish milky secretion, up to the beginning of the second week after the birth. In 14 cases, the transition type was obtained as intermediate product of the mother's milk, between colostrum and the mature milk, between the 7th and the 15 th day after the birth. In 14 cases, the mature type was obtained as a white opaque liquid, of light smell and sweet taste, from the 15 th day after birth.

The milk types obtained in the three presentations were subdivided according to the period of conservation and heating in the groups colostrum, transition and mature (Table 1).

TABLE 1 - Milk types according to the conservation period and heating

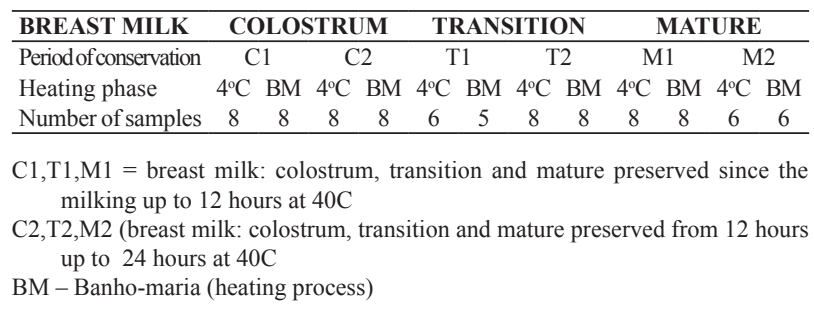

After collecting under aseptic technique accounting 8 $\mathrm{mL}$, was done the counting and analysis of the microbiologic safety of the mesophiles aerobics, total coliforms, Staphilococcus aureus and Salmonella sp for the consumption of the breast milk according to the resolution RDC n012 of the National Health Sanitary Vigilance ${ }^{1}$. The Adolfo Lutz Institute added analysis of fecal coliforms, Bacillus cereus, Molds/leavens and Pseudomonas aeruginosa.

The standard pattern of maximum tolerance determined by ANVISA $^{1}$ to aerobics mesophiles, total coliforms, Staphilococcus aureus and Salmonella sp, should not exceed taxes of bacterial growth in the breast milk of humans, in order to be considered acceptable for the consumption, such as: aerobics mesophiles - up to $102 \mathrm{UFC} / \mathrm{mL}$ (units to form colonies/mililiters); total coliform - absence NMP/ $\mathrm{mL}$ (most probable number/mililiter) or smaller or equal to $3 \mathrm{NMP} / \mathrm{mL}$; Staphilococcus aureus - absence UFC/mL or up to $102 \mathrm{UFC} / \mathrm{mL}$; Salmonella $s p$ - absence $/ 25 \mathrm{~mL}$.

At this moment, the Food Microbiology Service of Adolfo Lutz Institute, apart from analyzing the microbe agents mentioned, also established minimum taxes allowed to some microorganisms, indicators of the hygienic-sanitary patterns, such as: fecal coliforms - absence $\mathrm{NMP} / \mathrm{mL}$ or less or similar to $3 \mathrm{NMP} / \mathrm{mL}$; Bacillus cereus - absence UFC $/ \mathrm{mL}$ or up to $102 \mathrm{UFC} / \mathrm{mL}$; molds/leavens - absence or up to 10 $\mathrm{UFC} / \mathrm{mL}$; Pseudomonas aeruginosa - absence in $25 \mathrm{~mL}$.

For this study in particular, the Food Microbiology Service of Instituto Adolfo Lutz accepted as "no bacterial growth" the absence in $3 \mathrm{~mL}$, because of the limited quantity of the sample $(8 \mathrm{~mL})$ favoring the non-spoiling of the breast milk.

\section{Follow-up of the clinical evolution of the $N B$}

The NBs were from mothers between 21 up to 34 years of age with gestacional age between $284 / 7$ weeks up to $425 / 7$ weeks. The weight varied from $700 \mathrm{~g}$ up to $3.850 \mathrm{~g}$ in children of both genders and the Apgar Index 5-8-9 up to 8-9-9. Clinical manifestations indicating possible gastrointestinal disorder were observed as follows: diarrhea, abdominal sprain, abdominal coloring, erithema or progressive purple spots on the abdomen - indicating possible signs of peritonitis -, vomiting, orogastric probes residue, turgidity of the skin, hipoactivity, temperature variations, abdomen sensible to pain and intestinal loops enlarged.

\section{Statistical analysis}

The tests of Kruskal-Wallis and Wilcoxon were used in this statistical methods (non-parametric tests for independent samples) to compare the three presentations of the breast milk among themselves and the results of the milk were preserved at $4^{\circ} \mathrm{C}$ and underwent the heating process at $55^{\circ} \mathrm{C}$. It was accept $5 \%$ as significant level.

\section{RESULTS}

The microorganisms which did not presented growth were: Salmonella sp, Molds/leavens and Pseudomonas aeruginosa. The total coliforms and fecal coliforms were observed (Table 2 to 8 ). There was no significant microorganisms growth. The aerobic mesophiles, Staphilococcus aureus and Bacillus cereus could be observed (Figures 1 to 3). These microorganisms presented growth, but the NBs who were followed did not present their clinical status damaged.

TABLE 2 - Growth of total coliforms (NMP/ML), in the groups $\mathrm{C} 1 / \mathrm{Bw}-\mathrm{T} 1 / \mathrm{Bw}$ and $\mathrm{M} 1 / \mathrm{Bw}$

\begin{tabular}{|c|c|c|}
\hline \multicolumn{3}{|c|}{ Types of breast milk } \\
\hline Colostrum & Transition & Mature \\
\hline 3,0 & 3,0 & 210 \\
\hline 3,0 & 3,0 & 2400 \\
\hline 240 & 3,0 & 1100 \\
\hline 3,0 & 3,0 & 24000 \\
\hline 9,1 & 3,0 & 3,0 \\
\hline 3,0 & - & 3,0 \\
\hline 93,0 & - & 3,0 \\
\hline 3,0 & - & 3,0 \\
\hline \multicolumn{3}{|l|}{ Average } \\
\hline 44,6 & 3,0 & 3465,3 \\
\hline
\end{tabular}

Kruskal-Wallis tests $\chi 2$ calculated $=3,932$ N.S 
TABLE 3 - Growth of total coliforms (NMP/ML) in the groups $\mathrm{C} 2 / 4^{\circ} \mathrm{C}-\mathrm{T} 2 / 4^{\circ} \mathrm{C}$ and $\mathrm{M} 2 / 4^{\circ} \mathrm{C}$

\begin{tabular}{lll}
\hline Colostrum & $\begin{array}{c}\text { Types of breast milk } \\
\text { Transition }\end{array}$ & Mature \\
\hline 3,0 & 3,0 & 3,0 \\
3,0 & 3,0 & 3,0 \\
3,0 & 3,0 & 3,0 \\
3,0 & 3,0 & 3,0 \\
3,0 & 2400 & 3,0 \\
2400,0 & 3,0 & 3,0 \\
3,0 & 3,0 & - \\
3,0 & 3,0 & - \\
\hline
\end{tabular}

Statistic analysis dismissed

TABLE 4 - Growth of total coliforms (NMP/ML) in the groups $\mathrm{C} 2 / \mathrm{Bw}-\mathrm{T} 2 / \mathrm{Bw}$ and $\mathrm{M} 2 / \mathrm{Bw}$

\begin{tabular}{lll}
\hline Colostrum & $\begin{array}{c}\text { Types of breast milk } \\
\text { Transition }\end{array}$ & Mature \\
\hline 3,0 & 3,0 & 3,0 \\
3,0 & 3,0 & 3,0 \\
3,0 & 3,0 & 3,0 \\
3,0 & 3,0 & 3,0 \\
3,0 & 240 & 3,0 \\
240 & 3,0 & 3,0 \\
3,6 & 3,0 & - \\
3,0 & 3,0 & - \\
\hline
\end{tabular}

Statistic analysis dismissed

TABLE 5 - Growth of fecal coliforms (NMP/ML) in the groups $\mathrm{C} 1 / 4^{\circ} \mathrm{C}-\mathrm{T} 1 / 4^{\circ} \mathrm{C}$ and $\mathrm{M} 1 / 4^{\circ} \mathrm{C}$

\begin{tabular}{lll}
\hline Colostrum & $\begin{array}{c}\text { Types of breast milk } \\
\text { Transition }\end{array}$ & Mature \\
\hline 3,0 & 3,0 & 3,0 \\
3,0 & 3,0 & 3,0 \\
9,1 & 3,0 & 3,0 \\
3,0 & 3,0 & 3,0 \\
3,0 & 3,0 & 3,0 \\
3,0 & 3,0 & 3,0 \\
3,0 & - & 3,0 \\
3,0 & - & 3,0 \\
\hline
\end{tabular}

Statistic analysis dismissed

TABLE 6 - Growth of fecal coliforms (NMP/ML) in the groups $\mathrm{C} 1 / \mathrm{Bw}-\mathrm{T} 1 / \mathrm{Bw}$ and $\mathrm{M} 1 / \mathrm{Bw}$

\begin{tabular}{lll}
\hline Colostrum & $\begin{array}{c}\text { Types of breast milk } \\
\text { Transition }\end{array}$ & Mature \\
\hline 3,0 & 3,0 & 3,0 \\
3,0 & 3,0 & 3,0 \\
2400 & 3,0 & 3,0 \\
3,0 & 3,0 & 3,0 \\
3,0 & 3,0 & 3,0 \\
3,0 & - & 3,0 \\
3,0 & - & 3,0 \\
3,0 & - & 3,0 \\
\hline
\end{tabular}

Statistic analysis dismissed
TABLE 7 - Growth of fecal coliforms (NMP/ML) in groups of $\mathrm{C} 2 / 4^{\circ} \mathrm{C}-\mathrm{T} 2 / 4^{\circ} \mathrm{C}$ and $\mathrm{M} 2 / 4^{\circ} \mathrm{C}$

\begin{tabular}{lll}
\hline Colostrum & $\begin{array}{c}\text { Types of breast milk } \\
\text { Transition }\end{array}$ & Mature \\
\hline 3,0 & 3,0 & 3,0 \\
3,0 & 3,0 & 3,0 \\
3,0 & 3,0 & 3,0 \\
3,0 & 3,0 & 3,0 \\
3,0 & 3,0 & 3,0 \\
1500 & 3,0 & 3,0 \\
3,0 & 3,0 & - \\
3,0 & 3,0 & - \\
\hline
\end{tabular}

Statistic analysis dismissed

TABLE 8 - Growth of fecal coliforms (NMP/ML) in groups C2/ $\mathrm{Bw}-\mathrm{T} 2 / \mathrm{Bw}$ and $\mathrm{M} 2 / \mathrm{Bw}$

\begin{tabular}{lll}
\hline Colostrum & $\begin{array}{c}\text { Types of breast milk } \\
\text { Transition }\end{array}$ & Mature \\
\hline 3,0 & 3,0 & 3,0 \\
3,0 & 3,0 & 3,0 \\
3,0 & 3,0 & 3,0 \\
3,0 & 3,0 & 3,0 \\
3,0 & 3,0 & 3,0 \\
2400 & 3,0 & 3,0 \\
3,0 & 3,0 & - \\
3,0 & 3,0 & - \\
\hline
\end{tabular}

Statistic analysis dismissed

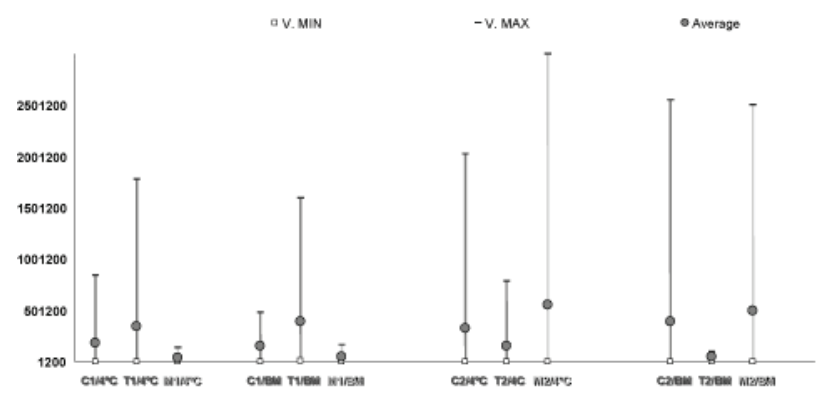

FIGURE 1 - Maximum, minimum, average values of aerobics mesophiles(UFC/mL) in the groups: $\mathrm{C} 1 / 4^{\circ} \mathrm{C}-\mathrm{T} 1 / 4 \mathrm{C}-\mathrm{M} 1 / 4^{\circ} \mathrm{C}$ $-\mathrm{C} 1 / \mathrm{BW}-\mathrm{T} 1 / \mathrm{BW}-\mathrm{M} 1 / \mathrm{BW}$ (colostrum, transition and mature since milking up to 12 hours $/ 4^{\circ} \mathrm{C}$ and $\mathrm{BW}$ ) $\mathrm{C} 2 / 4^{\circ} \mathrm{C}-\mathrm{T} 2 / 4 \mathrm{C}-\mathrm{M} 2 / 4^{\circ} \mathrm{C}-\mathrm{C} 2 / \mathrm{BW}-\mathrm{T} 2 / \mathrm{BW}-\mathrm{M} 2 /$ $\mathrm{BW}$ (colostrum, transition and mature of 12 hours up to 24 hours $/ 4^{\circ} \mathrm{C}$ and $\mathrm{BW}$ ) 


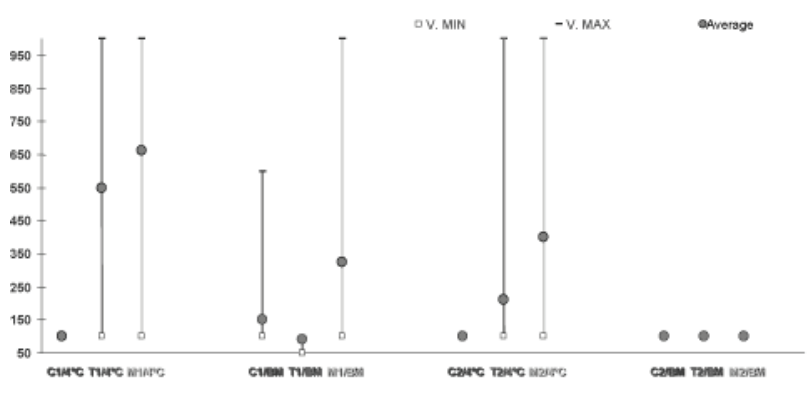

FIGURE 2 - Maximum, minimum and average growth of Stapholococcus aureus $(\mathrm{UFC} / \mathrm{mL})$ in the groups: $\mathrm{C} 1 / 4^{\circ} \mathrm{C}-\mathrm{T} 1 / 4^{\circ} \mathrm{C}-\mathrm{M} 1 / 4^{\circ} \mathrm{C}-\mathrm{C} 1 / \mathrm{BW}-\mathrm{T} 1 /$ $\mathrm{BW}-\mathrm{M} 1 / \mathrm{BW}$ (colostrum, transition and mature from milking up to 12 hours $/ 4^{\circ} \mathrm{C}$ and $\mathrm{BW}$ ) $\mathrm{C} 2 / 4^{\circ} \mathrm{C}-\mathrm{T} 2 / 4^{\circ} \mathrm{C}-\mathrm{M} 2 / 4^{\circ} \mathrm{C}-\mathrm{C} 2 / \mathrm{BW}-\mathrm{T} 2 \mathrm{BW}-$ $\mathrm{M} 2 / \mathrm{BW}$ (colostrum, transition and mature from 12 hours up to 24 hours $/ 4^{\circ} \mathrm{C}$ and $\mathrm{BW}$ )

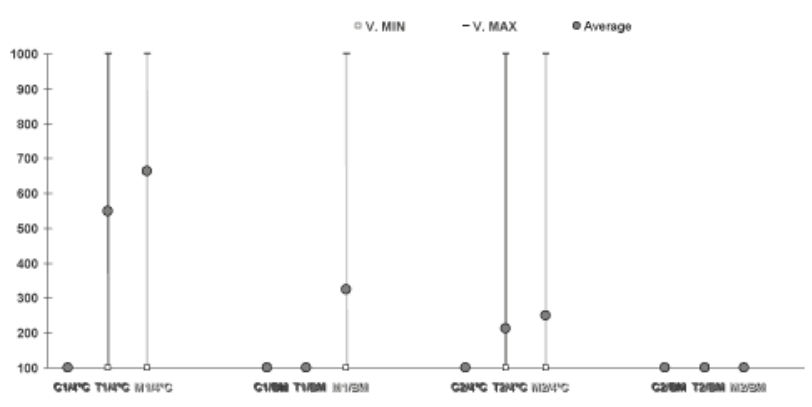

FIGURE 3 - Maximum, minimum and average of the growth of the Bacillus cereus $(\mathrm{UFC} / \mathrm{mL})$ in the groups: $\mathrm{C} 1 / 4^{\circ} \mathrm{C}-\mathrm{T} 1 / 4^{\circ} \mathrm{C}-\mathrm{M} 1 / 4^{\circ} \mathrm{C}-\mathrm{C} 1 / \mathrm{BW}-\mathrm{T} 1 /$ $\mathrm{BW}-\mathrm{M} 1 / \mathrm{BW}($ Colostrum, transition and mature since milking up to 12 hours $/ 4^{\circ} \mathrm{C}$ and $\mathrm{BW}$ ) $\mathrm{C} 2 / 4^{\circ} \mathrm{C}-\mathrm{T} 2 / 4^{\circ} \mathrm{C}-\mathrm{M} 2 / 4^{\circ} \mathrm{C}-\mathrm{C} 2 / \mathrm{BW}-\mathrm{T} 2 \mathrm{BW}-$ $\mathrm{M} 2 / \mathrm{BW}$ (Colostrum, transition and mature from 12 hours up to 24 hours $/ 4^{\circ} \mathrm{C}$ and $\mathrm{BW}$ )

\section{DISCUSSION}

There are several difficulties on providing stored human milk to the NB. There are other considerations as the vulnerability of the NB to infections and for its immature immunologic system, plus the possibility of consuming "in natura" milk which was not adequately handled while taken to the hospital. Therefore, it became necessary to investigate the microbiota of the hygienic conditions in this milk after storage and heating before being offered to the NB.

Eight groups of microorganisms which indicate the conditions recommended by health authority ANVISA ${ }^{1}$ and The Microbiological Alimentary Division of the Adolfo Lutz Institute were investigated. According to statistical analysis were applied non-parametric tests for independent samples.

It was observed that the aerobic mesophiles present in the stored milk at $4{ }^{\circ} \mathrm{C}$ and boiled water at $55^{\circ} \mathrm{C}$ for one minute, in the three stages as colostrum, mature and transition revealed a dispersion of their values, with no statistical significance.

Novak $^{7}$, assert that the microbiologic safety of the aerobic mesophiles must be up to $67 \mathrm{x} 104 \mathrm{UFC} / \mathrm{mL}$ to avoid possible gastrointestinal disorder to the NB. This value was related to less $8^{\circ} \mathrm{D}$ (Eight Dornic acidity degree). The more latic acid, the less availability of calcium and phosphorus on the milk to the NB.

The previous data confirm the large variation of the aerobic mesophiles found on the present study. Moreover, the average was $34 \times 104$. Therefore, according Novak ${ }^{7}$, the quantity of microorganisms is considered acceptable for the baby's consumption.

In other study, Castro ${ }^{3}$ also confirmed the large variation of the aerobic mesophilies analyzed on the raw human milk which is received in a human milk bank. Sixty samples were studied of raw or "in natura" human milk. The aerobic mesophiles were presented in $96,6 \%$ of the total amount of samples, being $17,24 \%$ (10 samples) with a variation of 1 to $99 \mathrm{UFC} / \mathrm{mL} ; 17,24 \%$ (10 samples) between 102 and 9,9x102 UFC/mL; 10,34\% (6 samples) were between 103 and 9,9x103 UFC/mL; 25,86\% (15 samples) between 104 and 9,9x104 UFC/mL; 17,24\% (10 samples) between 105 and 9,9x105 UFC/mL; 10,34\% (6 samples) between 106 and 9,9x106 UFC/mL and in 1,72\% (1 sample) between 107 and 9,9x107 UFC/mL. However $3,33 \%$ ( 2 samples) showed to be negative.

Concerning the total coliforms, it was observed a more uniform bacterial growth among the periods of human milk preservation. Most of the data were within microbiological pattern accepted by Health authorities. However, it was observed that since the milking up to 12 hours, four cases of mature milk and two cases of colostrum, presented excessive colonization and after 12 hours up to 24 hours, in which isolated cases, were seen which could mean contamination due to handling.

Microbiological analysis of 60 samples of raw human milk which were received in a human milk bank revealed many microorganisms, including total coliforms. The results were E. coli microorganism positive in $50 \%$ of the analyzed samples and total coliforms in $75 \%$. From the total analyzed samples, the population of E. coli was positive in $93,33 \%$ ( 28 samples) with a variation between 1 and $99 \mathrm{NMP} / \mathrm{mL} ; 3,33 \%$ (1 sample) was between 104 and $9,9 \times 104 \mathrm{NMP} / \mathrm{mL} ; 3,33 \%$ (1 sample) was from 105 to $9,9 \times 105 \mathrm{NMP} / \mathrm{mL}$. The population of the total coliforms which was positive in $57,77 \%$ (26 samples) of the total analyzed samples were between 1 and $99 \mathrm{NMP} / \mathrm{mL}$; $24,4 \%$ (11 samples) were between 102 and 9,9x102 NMP/ $\mathrm{mL} ; 2,22 \%$ (1 sample) were between 103 and 9,9x103 $\mathrm{NMP} / \mathrm{mL} ; 8,88 \%$ (4 samples) were between 104 and 9,9x104 NMP/mL; 4,44\% (2 samples) between 105 and $9,9 \times 105 \mathrm{NMP} / \mathrm{mL}$ and in 2,22\% (1 sample) from 106 to 9,9x106 NMP/mL3.

The fecal coliformes in the milk preserved at $4^{\circ} \mathrm{C}$ and heated at $55^{\circ} \mathrm{C}$ for one minute, in the three stages (colostrum, transition and mature) did not show statistic significance.

This data were not showed by Novak, et al.6 who 
studied 821 human milk samples randomly obtained from flasks filled by the donors at home. A total of 48 strains of mycelial fungi were isolated from the human milk bank samples and identified through standard laboratory techniques. The microbiological analysis revealed the occurrence of molds and yeasts in 43 samples $(5.2 \%)$, with counts reaching $103 \mathrm{CFU} / \mathrm{mL}$. The following microorganisms were identified: Aspergillus niger group (6.3\%), Aspergillus sp. (4.2\%), Paecilomyces sp. (12.6\%), Penicillium sp. (60.4\%), Rhizopus sp. (2.0\%), and Syncephalastrum $s p$. (14.5\%). Four samples showed the presence of more than one mycelial fungus type. Therefore, the presence of molds and yeasts in human milk manually expressed at home suggests that the hygiene conditions of the collection site may contaminate milk. Thus, when hospitalized premature babies receive the raw product, it is very important to observe the collection, storage and transport. However, the consequences of contaminants increase was not studied.

The analysis of the Staphilococcus aureus showed a significant statistic growth, $\mathrm{x}=7,078$, in the transition and mature groups, in relation to colostrum since the milking up to 12 hours, kept at $4^{\circ} \mathrm{C}$. According to Calil, et al. ${ }^{2}$ probably the concentration of immunoglobulins and lactoferrin being higher in the colostrum offers the protective action, inhibiting the bacterial proliferation.

Castro $^{3}$, in her microbiological analysis of the raw human milk confirm the data about the average found of the Staphilococcus aureus. From the 60 samples analyzed, the Staphilococcus aureus group presented in 78,57\% (22 samples) with a variation between 1 and $99 \mathrm{UFC} / \mathrm{mL}$; $3,57 \%$ ( 1 sample) between 102 and $9,9 \times 102 \mathrm{UFC} / \mathrm{mL}$; $10,71 \%$ (3 samples) between 103 e 9,9x103 UFC/mL and $7,14 \%$ ( 2 samples) were between 104 and 9,9x104 UFC/ $\mathrm{mL}$. However, the author do not mentioned which stage of milk (colostrum, transition and mature) was found more microorganisms of this group and the consequences of contaminants increase to the NB.

Concerning the results of Bacillus cereus in the transition and mature groups, between the milking up to 12 hours, kept at $4^{\circ} \mathrm{C}$, there was a pattern of growth similar to the one of the Staphilococcus aureus, in accordance with the some kind of protection atributed to the immunoglobulins.

Regarding the molds/leavens, Salmonella $s p$ and Pseudomonas aeruginosa, they showed similar results in both periods, with no significant values and no growth.

On the other hand, Novak, el at. ${ }^{6}$ studied 821 human milk samples randomly obtained from flasks filled by the donors at home and a total of 48 strains of mycelial fungi were isolated by standard laboratory techniques.
The microbiological analysis revealed the occurrence of molds and yeasts in 43 samples (5.2\%), with counts reaching $103 \mathrm{CFU} / \mathrm{mL}$. The following microorganisms were identified: Aspergillus niger group (6.3\%), Aspergillus sp. (4.2\%), Paecilomyces sp. (12.6\%), Penicillium sp. (60.4\%), Rhizopus sp. (2.0\%), and Syncephalastrum $s p .(14.5 \%)$. Four samples showed the presence of more than one mycelial fungus type. Therefore, the presence of molds and yeasts in human milk manually expressed at home suggests that the hygiene conditions of the collection site may contaminate milk. Thus, when hospitalized premature babies receive the raw or "in natura" human milk, it is very important to observe the collection, storage and transport. However, the consequences of contaminants increase was not studied.

About the 29NB who had ingested the breast milk "in natura", 28 presented a stable clinical evolution, from the gastrointestinal point of view, indicating that even with the large variable of mesophiles found, there was no damage to the clinical status of the NBs. However, a NB who was a twin baby, presented abdominal sprain, orogastric probes residue, hipoactivity, abdomen sensible to pain and intestinal loops enlargement. It was diagnosed paralysed ileum by the neonatal medical team.

According to Margotto ${ }^{5}$ and Zilberstein, et al. ${ }^{9}$ the gastrointestinal flora of the NB is made of gram-negatives, which in the presence of different agents such as perinatal asfixia, can lead to the loss of defense factors of the digestive system with a decreased protection of the mucus, exposing the cells to the enzymatic digestion, allowing the bacterial invasion, which symbiotically inhabits the gastrointestinal tract of the NB, after some hours after birth. Fortunately, the NB, the second twin, even after receiving the same breast milk offered to his brother, didn't have gastrointestinal disorders, probably suggesting that the bacterial charge in the breast milk was not responsible for the gastrointestinal problems in the first twin.

\section{CONCLUSIONS}

Under this conditions of collecting and storage, there was no fecal coliforms, Salmonella $s p$, Molds/leavens, and Pseudomonas aeruginosa; the microorganisms which grew up, kept themselves above the limits of detection (aerobic mesophiles, total coliforms, Stapholococcus aureus and Bacillus cereus; microbian rates, even when higher than the ones stablished, did not influence the clinical status of the NB; the breast milk collected, transported and stored under the conditions presented in this study can be safely used up to 24 hours after being stored in a refrigerator at $4^{\circ} \mathrm{C}$. 
Borrell JG, Zilberstein B, Quintanilha AG. Influência do armazenamento e aquecimento na microbiota do leite materno. ABCD Arq Bras Cir Dig 2009;22(1):19-24

RESUMO - Racional - Existe consenso que os recém-natos são particularmente propensos a desenvolverem infecções gastrointestinais devido a múltiplos fatores dentre eles a hipóxia. Há facilidade de colonização anormal e destruição de bactérias com absorção de toxinas. Objetivo - Identificar micro-organismos no leite materno depois de estocado em refrigerador a $4^{\circ} \mathrm{C}$ e também depois do aquecimento, e pesquisar se os sinais laboratoriais encontrados teem alguma correlação clínica. Métodos - As amostras coletadas contemplaram as três fases do leite materno. Em 16 casos, colostro foi obtido como amarelado até a segunda semana do nascimento. Em 14 casos o tipo transicional, entre colostro e leite maduro, ocorreu de sete e 15 dias depois do nascimento. Em 14 casos o leite maduro foi obtido também entre sete e 15 dias. Os diversos tipos foram subdivididos de acordo com o período de conservação e de aquecimento. Resultados - Os micro-organismos que não cresceram foram: Salmonella sp, Molds/leavens e Pseudomonas aeruginosa. Foram observados coliformes totais e fecais. Não ocorreu crescimento bacteriano significativo. Cresceram mesófilos aeróbicos, Staphilococcus aureus e Bacillus cereus. Embora com esses crescimentos, não houve repercussão clínica nos recém-nascidos. Conclusões - Nas condições propostas neste estudo, não houve crescimento significativo de coliformes fecais, Salmonella sp, Molds/leavens e Pseudomonas aeruginosa; os micro-organismos que cresceram mantiveram-se acima no nível de detecção (mesófilos aeróbicos, coliformes totais, Stapholococcus aureus e Bacillus cereus). As taxas de micro-organismos mesmo sendo mais altas que as estabelecidas como toleráveis não influenciaram na estabilidade clínica dos recém-nascidos; o leite materno coletado, transportado e armazenado nas condições deste estudo foram seguras e podem ser utilizadas até 24 horas após terem sido armazenadas em refrigerador a $4^{\circ} \mathrm{C}$.

DESCRITORES - Leite humano. Microorganismos.

\section{REFERENCES}

1. ANVISA. Agência Nacional de Vigilância Sanitária. Resolução-RDC n ${ }^{\circ} 12$, de 02 de janeiro de 2001.Regulamento Técnico sobre padrões microbiológicos para alimentos. [online]. Disponível em: <http://www.anvisa.gov.br/legis/resol/ index_2001_red.htm $>$ (07 ago 2008)

2. Calil VMLT, Leone CR, Ramos JLA. Composição nutricional do colostro de mães de recém-nascidos de termo adequados e pequenos para a idade gestacional e principais vantagens do leite materno. [Parte de Dissertação de Mestrado online] Faculdade de Medicina da Universidade de São Paulo. Disponível em: <http://www.pediatriasaopaulo.usp.br> (06 ago.2008)

3. Castro MRCC. Avaliação da qualidade microbiológica de leite humano cru recebido em Banco de Leite Humano.[Dissertação] Piracicaba (SP): Escola Superior de Agricultura Luiz de Queiroz (ESALQ);2006

4. Heck AR, Sakomoto LM, Santos VR. Controle de qualidade em Banco de Leite Humano: técnicas [Apresentado I Congresso Paulista de Bancos de Leite Humano, $2001 \operatorname{dez} 1$; Ribeirão Preto]

5. Margotto PR. Enterocolite Necrosante no recém-nacido a termo: estudo de caso-controle e revisão de literatura.. J.Perinatolol [periódico online] 2004;24:494-99. Disponível em: <http://www.paulomorgatto.com.br/ documentos/ECN_RTermo.doc $>$ (07 ago. 2008)
6. Novak FR, Almeida JAG, Santos MJS, Wanke B. Contamination of expressed human milk by Mycelial fungi. J. Pediatr.2002. V. 78 (3):183-4.

7. Novak FR; Cordeiro DMB. Correlação entre população de microrganismos mesófilos aeróbios e acidez Dornic no leite humano ordenhado J. Pediatr., 2007. v.83(1): 87-91.

8. UNESP. Definições do leite humano: colostro, transição e maduro. [online] São Paulo; Universidade Estadual Paulista; 2008. Disponível em: $<$ http://www. rc.unesp.br/proama/pagfeitas/colostro.htm $>$ ( 18 ago 2008)

9. Zilberstein B; Quintanilha AG; Santos MAA; Pajecki D; Moura EG; Alves PRA; Maluf Filho F; Souza JAU; Rodrigues JG. Microbiota no trato digestivo em voluntários saudáveis. Clinics [periódico online] 2007;.62(1):47-54. Disponível em: $<$ http://www.scielo.br/scielo.ph $P>$ ( 20 mar. 2008)

Fonte de financiamento: não há Conflito de interesse: não há Recebido para publicação: 25/07/2008 Aceito para publicação: 02/11/2008 